\title{
Appropriate Technology and Field Application of Non-powered Water Purification System Using Nanofiber Membrane
}

\author{
Jin Lee ${ }^{1}$, Byeong Gweon Yun ${ }^{1}$, Kyoung Gu Han ${ }^{1}$, Seung Hoon Lee ${ }^{1}$, Cheol Hyeon Kim¹, \\ Chan Kim ${ }^{1, \dagger}$, Yunho Lee ${ }^{2}$, Dongwhi Lee ${ }^{2}$, Seunghyeok Lee ${ }^{2}$, Kyoung-Woong Kim² \\ ${ }^{1}$ Amogreentech Co., Ltd. 609-1, Wolha-ro, Haseong-myeon, Gimpo-si, Gyeonggi-do, Republic of Korea \\ ${ }^{2}$ School of Earth Sciences and Environmental Engineering, Gwangju Institute of Science and Technology (GIST), \\ Gwangju 61005, Korea

\section{나노섬유 멤브레인 기반 무동력 정수 시스템의 적정기술 및 현장 적용}

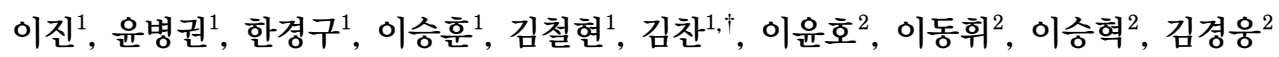 \\ 1(주)아모그린텍 신소재 연구소 \\ ${ }^{2}$ 광주과학기술원(GIST) 지구환경공학부
}

\begin{abstract}
안전한 음용수 확보를 위한 적정기술로써 환경적, 기술적 요구사항을 충족할 수 있는 나노섬유 멤브레인으로 구성된 무동력 막 여과 시스템을 평가하였다. 이 장치는 수두차에 의한 중력과 생물학적 막 오염층 제어로 별도의 에너지원 이 필요 없고, 핵심 소재인 PVDF 나노섬유 멤브레인 필터가 병렬로 연결, 모듈화되어 있어 물 생산성을 높이는 구조 이다. 이 장치의 실제 현장 적용 가능성을 평가하기 위해 Pilot-scale (3000-5000 L/day) 나노섬유 멤브레인 기반 정수 시스템이 개발도상국(키리바시, 투발루 등)에 2017년 8월 설치되어 3 개월간 운영되었다. $14-92 \mathrm{~L} /\left(\mathrm{m}^{2} \times \mathrm{h}\right)$ 의 플럭스로 안정적 물 생산성을 확인하였고 처리수의 탁도와 박테리아의 높은 제거율 $(99.99 \%$ 이상)로 안전한 수질을 장기간 제 공할 수 있음을 확인하였다. 이러한 결과는 현장 적용을 통해 나노섬유 멤브레인 기반 무동력 정수 시스템이 장기간 안전한 음용수를 공급할 수 있는 정수장치로 평가되었고, 적정기술로써 개도국의 수처리 장치로 활용 가능성을 보여 준다.
\end{abstract}

Gravity-driven membrane (GDM) filtration system based on the nanofiber membrane was investigated. This system can be operated with little energy demand due to a gravitational pressure-driven filtration and biological fouling control strategy. Moreover, the optimal module configuration based on the high permeance of nanofiber membrane can provide a significantly high water productivity. In order to evaluate its applicability potential, the pilot-scale (3000-5000 L/day) systems with nanofiber membranes were operated in developing countries (Kiribati and Tuvalu). Our results showed that the 14$92 \mathrm{~L} /\left(\mathrm{m}^{2} \times \mathrm{h}\right)$ of the permeate flux was determined indicating a stabilized water productivity. In addition, the permeate water indicated a high removal rate (more than $99.99 \%$ ) of turbidity and bacteria. Consequently, the system can provide a stabilized water production with safe permeate water quality during long-term operation. These findings exemplify an effective approach to decentralized drinking water treatment for developing countries.

KEYWORDS: Nanofiber membrane, Decentralized water treatment, Gravity-driven membrane filtration, Permeate water quality

\footnotetext{
${ }^{\dagger}$ To whom correspondence should be addressed.

E-mail: ckim@amogreentech.co.kr

Received: 22 March 2021, Revised : 8 June 2021,

Accepted: 8 June 2021
} 


\section{Introduction}

인구증가와 공업화, 기후변화에 따른 물 부족 현상에 관 한 관심이 증가하고 있으며, 안정적이며 효율적인 수자원 확 보를 위한 수처리 기술에 대한 요구가 확대되고 있다. 수처 리 기술은 물에 함유된 오염 및 유해 물질을 제거하여 물 의 효율적인 공급과 관리, 안정성을 확보하기 위한 것으로, 정수, 오·폐수 처리, 해수 담수화 등 다양한 분야가 있으며 여러 수처리 기술 중 멤브레인을 이용한 기술이 가장 효과 적인 대안으로 부상하고 있다(Cha and Kim, 2012). 반투과 성(semi-permeable)의 멤브레인을 이용한 수처리 기술은 원 수 내 함유된 각종 오염물질에 대한 높은 제거능과 화학물 질의 사용 및 배출이 없으며, 모듈의 확장성과 기존 공정 대 비 높은 에너지효율로 수도수 정수 분야에서 반도체 공정 의 초순수 제조까지 다양하고 빠른 속도로 발전하고 있다 (Lee et al., 2013). 이러한 멤브레인을 적용한 수처리 공정 기술은 지난 수십 년간 괄목할만한 기술적 진보가 이루어 졌으나 성공적으로 상용화된 멤브레인은 극히 제한적이며, 각종 수처리 분야의 시장 확대와 더불어 깨끗한 물에 대한 수요로 인해 높은 제거율과 투과도를 동시에 만족하는 새 로운 고성능 멤브레인에 대한 요구가 있다. 더욱이, 막 표 면 위 막 오염층의 존재는 막 여과 운영효율 감소와 주기 적인 막 교체를 요구하여 다양한 막오염층 제어 연구가 진 행되고 있다.

일반적으로 수처리용 필터여재는 섬유나 다공성 고분자 여과 매체 이들이 복합화된 막의 형태를 가지는 공통점이 있다. 다공성 고분자 여과 매체인 고분자 막이나 중공사 막 은 제조 시 포함된 기공 형성제를 소결시키거나 외부 응고 액에 용해시키는 방법 등을 통해 기공을 형성한다. 또한 고 어텍스로 대표되는 PTFE(poly-tetrafluoroethylene) 막은 필 름을 이축 연신시키거나 상분리 등의 방법을 통해서 제조 된다. 이에 반해 섬유로부터 형성된 부직포상 여과 매체는 제조된 단섬유를 집적시킨 후 열과 압력 등을 가하여 제조 되거나 방사와 동시에 부직포상의 시트로 제조되고 있다. 그 러나 일반적인 합성섬유를 이용한 부직포의 기공은 단섬유 의 직경, 제조방법, 두께 등의 인자에 의해 결정되는데 부 직포에 포함되는 단섬유의 직경은 수 수십 $\mu \mathrm{m}$ 단위로 두 께와 제조방법의 조절만으로는 정밀 여과막 정도의 필터여 재만 구현하는 정도이다. 이를 해결하기 위해 고안된 방법 이 섬유의 직경을 $1 \mu \mathrm{m}$ 미만의 나노섬유로 필터여재를 제 조하는 것이다. 이러한 나노섬유의 제조방법으로는 화학적 기상증착(CVD), 자기조립(self-assembly), 드로잉(Drawing), 전기방사(electrospinning)법 등 다양한 방법이 있으나 생산 성, 응용 가능성 측면에서 전기방사법이 가장 효과적이다.
전기방사에 의한 나노섬유의 제조는 합성 및 천연 고분 자 약 100 여 종이 방사되는 것으로 알려져 있으나, 양산화 (Roll 방사)되어 산업화에 응용되는 고분자로는 PVDF (Polyvinylidine fluoride), PAN(polyacrylonitrile), PU(polyurethane), PVA(polyvinyl alcohol) 등 몇몇 고분자에 한정되 어 있다(Lee et al., 2017; Lee et al., 2020). 특히 수처리용 필터여재의 중요한 물성 중의 하나로는 유량을 들 수 있는 데 이는 필터여재의 기공도, 기공 크기, 기공구조 뿐만 아 니라, 필터여재의 친수화 정도에도 영향을 받는다. 따라서 친수성이 부족한 재질의 필터여재는 막 표면을 플라즈마 처 리, 친수성기로 표면개질, 별도의 친수성층을 코팅하는 등 의 다양한 방법을 통해 유량을 증가시켜 왔다. PVDF는 불 소계 고분자 중 대표적인 치수안정성, 우수한 내화학성과 내 후성, 내마모성을 보유하고 있으면서 전기방사 시 균일한 섬 유 직경분포와 세공구조를 제어할 수 있으나 강한 소수성 (hydrophobic) 특징으로 인해 수처리용 멤브레인으로 응용 시 표면 친수화를 진행하여 수투과 용량을 증가시킬 필요 가 있다.

최근 전기방사(electrospinning)법에 의해 제조되는 나노섬 유(nanofiber)는 섬유의 직경과 적층된 시트(sheet)의 두께로 기공의 크기를 제어할 수 있는 신개념 멤브레인으로 기존 연신 및 상분리(phase separation) 방법으로 제조된 멤브레인 대비 높은 수 투과성과 제거효율을 나타낼 수 있어 다양한 형태로 수처리 분야에 적용할 수 있다. 전기방사는 고분자 용융물에 고전압을 인가하여 노즐과 집전체 간 형성된 전 계(電界)에 의해 직경 $1 \mu \mathrm{m}$ 미만의 나노섬유로 구성된 부직 포상의 멤브레인을 얻는 방법이다. 전기방사에 의한 나노섬 유는 표면(表面)에서 이면(裏面)까지 기공이 무작위로 연결 된 3차원 망상구조로 단위 부피당 비표면적이 넓고, $60 \sim 80 \%$ 의 높은 기공률을 가져 투습 방수용 의류 분야, 의료용 멤 브레인, 수처리 및 공기정화용 필터류, 전기·전자 기기용 부 품까지 다양하게 적용되고 있다(Lee et al., 2017).

반응기 내 수두차를 이용한 무동력 막 여과 시스템이 저 에너지 수처리 기술로 주목을 받고 있다. 이 시스템은 막 모 듈과 원수 수두 차이로 발생하는 압력으로 구동되어 에너 지 소비가 적고, 생물학적 막 오염층 제어(섭식 활동)로 주 기적인 막 세척/교체 없이 장기간 운영이 가능하기 때문이 다. 하지만, 막 표면 위 오염층의 존재는 기존 고압의 막여 과 시스템보다 상대적으로 낮은 물 생산성으로 이어져 널 리 적용하는 데 큰 장애 요소로 나타나고 있다. 따라서 나 노 섬유 멤브레인 적용은 상대적으로 높은 수 투과성으로 초기 높은 물 생산성으로 이어질 수 있다. 특히, 나노섬유 멤브레인을 초저압력 조건에서 운영하게 되면 높은 기공률 로 인한 처리용량의 증가와 물리 세척 없이도 장기간 일정 
수량을 여과할 수 있는 환경친화적인 막 여과 기술을 제공 할 수 있다. 이러한 나노섬유 멤브레인으로 구성된 수처리 용 평막은 재난지역이나 상수관로가 없는 지역, 전력 등 인 프라 구축이 어려운 지역, 정수, 정화기술이 부족한 저개발 도상국 등의 환경과 여건에 맞는 적정기술(appropriate technology)로써 활용성이 높은 특징이 있다. 적정기술용 정 수장치는 사용자가 쉽게 이용할 수 있으며 유지보수가 간 편한 사용자 편리성과 장기 운전이 가능해야 하며, 음용수 에 적합한 수질의 물을 빠르게 생산해야 한다. 하지만, 현 장 적용을 고려한 실증화 연구는 제한적이고 막 세척 없이 장기간 운영되는 중력식 막 여과 시스템의 효율평가는 필 수적이다.

본 연구에서는 안전한 음용수 확보를 위한 적정기술로써 환경적, 기술적 요구사항을 충족할 수 있는 나노섬유 멤브 레인기반 무동력 정수 시스템의 현장 적용 가능성과 시스 템 운영효율을 평가하였다. 실제 규모(Pilot scale, 3000-5000 $\mathrm{L} / \mathrm{day}$ ) 시스템이 개발도상국(키리마시, 투발루) 현지에 설치 되어 장기 운영되었다. 이 장치의 실증실험을 통하여 물 생 산성과 탁도와 박테리아 제거율을 포함한 처리수의 수질 모 니터링을 통해 안전한 수질을 장기간 제공 가능한지를 평 가하고자 한다. 또한 이 장치의 GIST(광주과학기술원) 희망 정수기 옹달샘 프로젝트 해외 적용사례를 통해 적정기술로 써 가능성을 시사하고자 한다.

\section{Materials and Methods}

\section{1. 나노섬유 멤브레인}

전기방사용 고분자로는 분자량 $(\mathrm{Mw}) 441,000$ 의 $\mathrm{PVDF}$ (Polyvinylidine fluoride, Kynar 761, homo, Arkema, USA)을 $\mathrm{DMAc}$ (Dimethylacetamide, 덕산화학)와 Acetone(덕산화학)

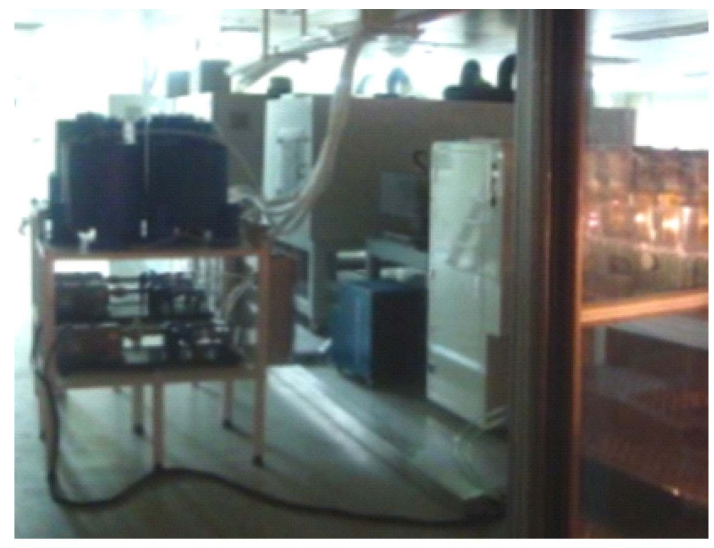

(a)
의 함량이 $90 / 10 \mathrm{vol} . \%$ 인 혼합용매로 농도 $15 \sim 19 \mathrm{wt} . \%$ 가 되 도록 방사용액을 제조하였다. 제조된 방사용액은 정량펌프 를 사용하여 노즐이 장착된 전기방사 팩에 분당 50 150 $\mu \ell / \mathrm{hole}$ 로 공급하였으며, 고전압 발생장치로는 모델명 AU100R6(Matsusada, Japan)을 이용하여 집전체(collector)에 $(-)$ 전극을 접지하여 방사하였다. 방사실의 온도와 습도는 각 각 $30 \sim 32^{\circ} \mathrm{C}, 50 \%$ 를 유지했으며, 인가전압 $70 \sim 80 \mathrm{kV}$ 로 조 절하면서 전기방사를 실시하였다. 이때 방사 폭은 $1.5 \mathrm{~m}$ 로 길이 $300 \mathrm{~m}$ 씩 박리지(transfer paper)에 토출량과 방사 시간 을 조절하여 소정의 평량 $(\mathrm{gsm})$ 이 되도록 롤(roll) 방사를 하 였다. 각각 제조된 나노섬유 시트는 $150^{\circ} \mathrm{C}, 100 \mathrm{~g} / \mathrm{cm}^{3}$ 의 조 건으로 캘린더링(calendering) 후, 박리지 제거를 위하여 리 와인딩(re-winding)하여 PVDF 나노섬유로만 구성된 시트를 얻었다. Figure 1에는 (주)아모그린텍의 전기방사 설비 및 나 노섬유 제품의 사진을 나타냈다. 나노섬유의 표면 모폴러지 분석은 FE-SEM(Hitachi, S-4200, Japan)을 사용하여 분석하 였으며, 제조된 섬유의 평균 직경은 이미지 분석 프로그램 (Nanofiber vision, Aomgreentech)으로 측정하여 평균 섬유의 직경을 구하였다. 또한 제조된 $\mathrm{PVDF}$ 의 표면을 친수성 고 분자인 PVA(poly vinylachol)을 표면 코팅 후 열 가교처리하 여 친수성을 부여하였다.

나노섬유의 기공 분포 및 공기 투과도는 PMI 장비(PMI Capillary Flow Porometer, Swiss)를 사용하여 ASTM D737 (Standard test method for air permeability of textile fabrics) 법으로, 인장강도는 만능시험기(Instron 5582, USA)를 사용 하여 $100 \mathrm{~N}$ 의 Load Cell을 장착한 뒤 방사된 섬유를 ASTM D-638-5법으로 평가하였다.

\section{2. 무동력 정수 시스템}

Figure 2에는 (주)아모그린텍의 무동력 정수 시스템의 기본

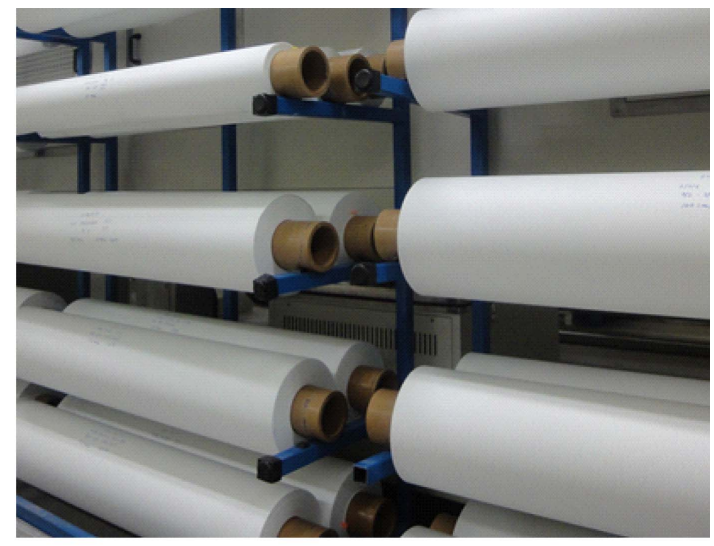

(b)

Figure 1. Photographs of (a) Amogreentech's electrospinning equipment and (b) nanofiber products. 
개념과 구조를 나타냈다. 무동력 정수장치용 필터모듈(GDMmodule, Gravity-Driven Membrane filter module)은 원수 내 에 잠긴 상태에서 중력 또는 위치에너지에 기인한 수압을 통해 원수가 필터층으로 흡입됨으로써 원수에 포함된 이물 질을 제거하여 여과수를 생산하는 구조이다. 무동력 정수 시 스템은 PVDF 나노섬유 멤브레인(평균 기공 크기 : 0.2, 0.3, $0.45 \mu \mathrm{m})$ 이 가로, 세로 각각 $27.1 \mathrm{~cm} \times 61.9 \mathrm{~cm}$ 의 평막 형태 의 필터 유닛이 병렬로 연결되어 모듈을 형성하고, 필터 테 두리는 기계적 특성과 내구성이 우수한 $\mathrm{ABS}$ (acrylonitrile butadiene styrene) 소재로 밀봉되어 프레임에 고정하는 형태 이다. 무동력 정수 시스템의 구성은 원수에 함유된 거대 입 자나 불순물을 제거하는 프리 스크린(Pre-screen)이 설치된 수조 내에 무동력 막 여과 시스템 2 대가 병렬로 연결, 고정
되어 있으며, 중력에 의해 정수된 물은 저장탱크로 이송되 는 구조이다. Figure 3에는 (주)아모그린텍의 대표적인 무동력 정수 시스템용 무동력 막 여과 시스템의 사진을 나타냈다.

\section{3. 무동력 정수 시스템 파일럿 성능 평가}

무동력 정수 시스템의 성능 및 장기 효율 평가는 Figure 4 와 같은 시간당 $60 \mathrm{~L}$ 이상의 처리수를 생산할 수 있는 3000 $\mathrm{L} / \mathrm{day}$ 규모의 파일럿(Pilot)을 광주과기원(GIST) 내에 설치 하여 실시하였다. 파일럿의 무동력 막 여과 시스템 집수면 적은 약 $60 \mathrm{~m}^{2}$, 필터 면적은 $8,052 \mathrm{~m}^{2}$ 로 인입수인 빗물을 활 용하여 평가하였으며, 탁도 측정은 인입수와 처리수에 대해 Hach사의 탁도 측정기(DR-2100, Germany)를 이용하였다. 미생물 제거성능은 종속 영양 박테리아를 인입수와 처리수

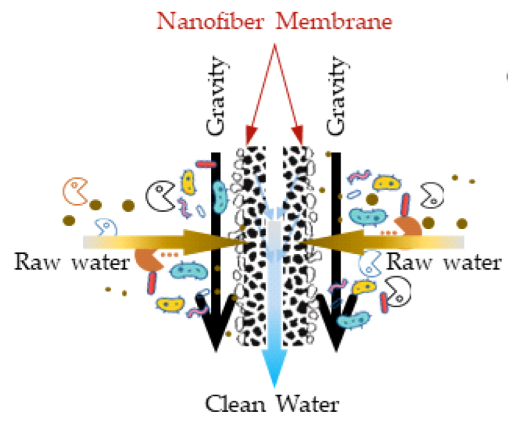

(a)

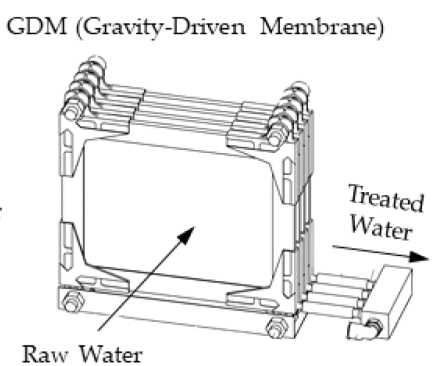

(b)

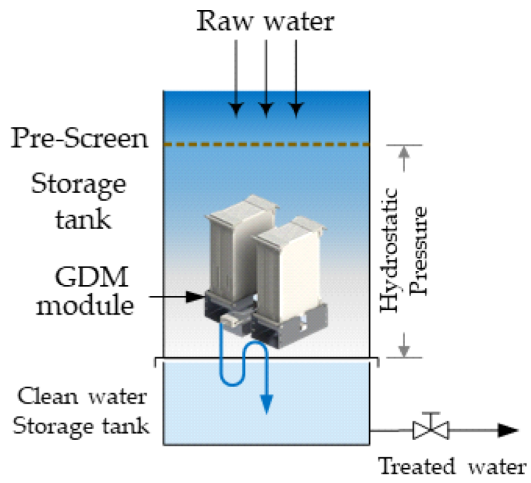

(c)

Figure 2. A illustration of GDM system, (a) basic concept, (b) GDM unit, and (c) Non-powered water purification system.

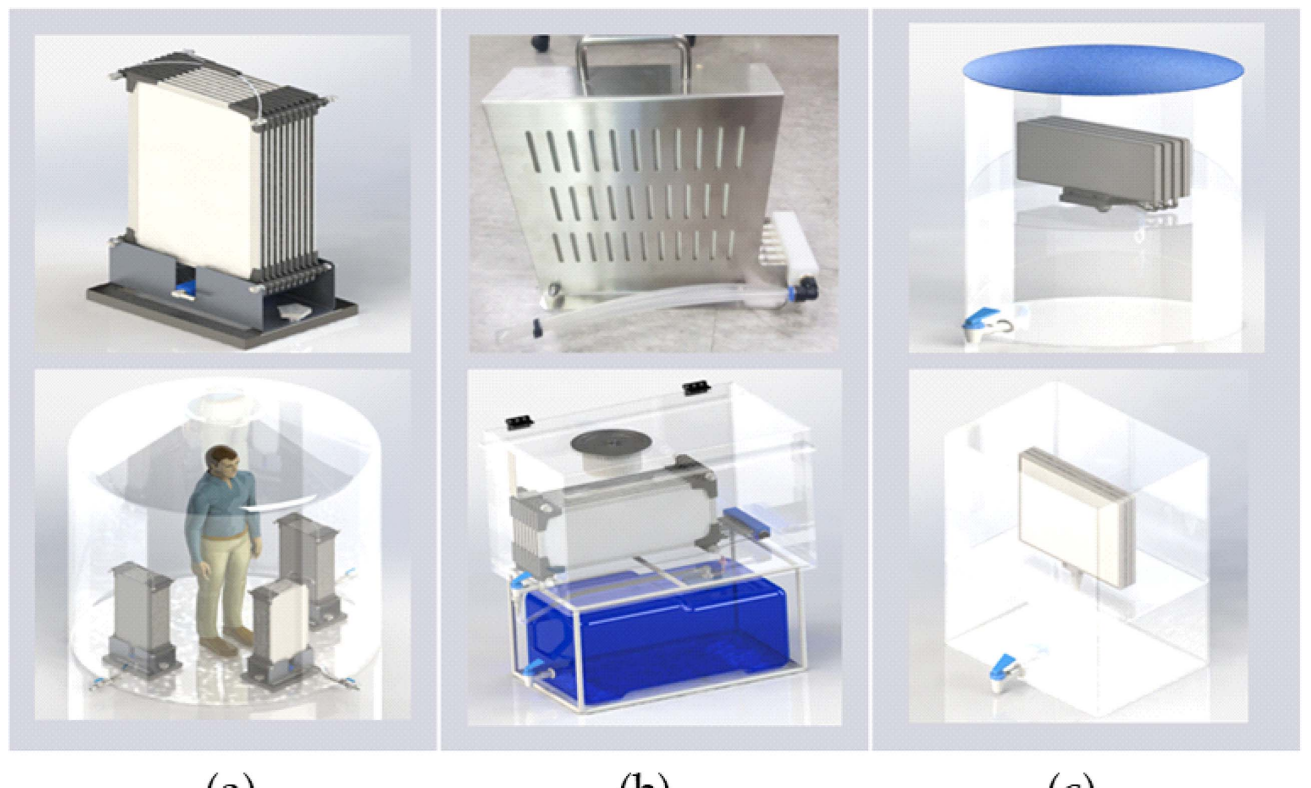

(a)

(b)

(c)

Figure 3. Amogreentech's non-powered water purification system, (a) Small size, (b) Middle size, and (c) Big size. 


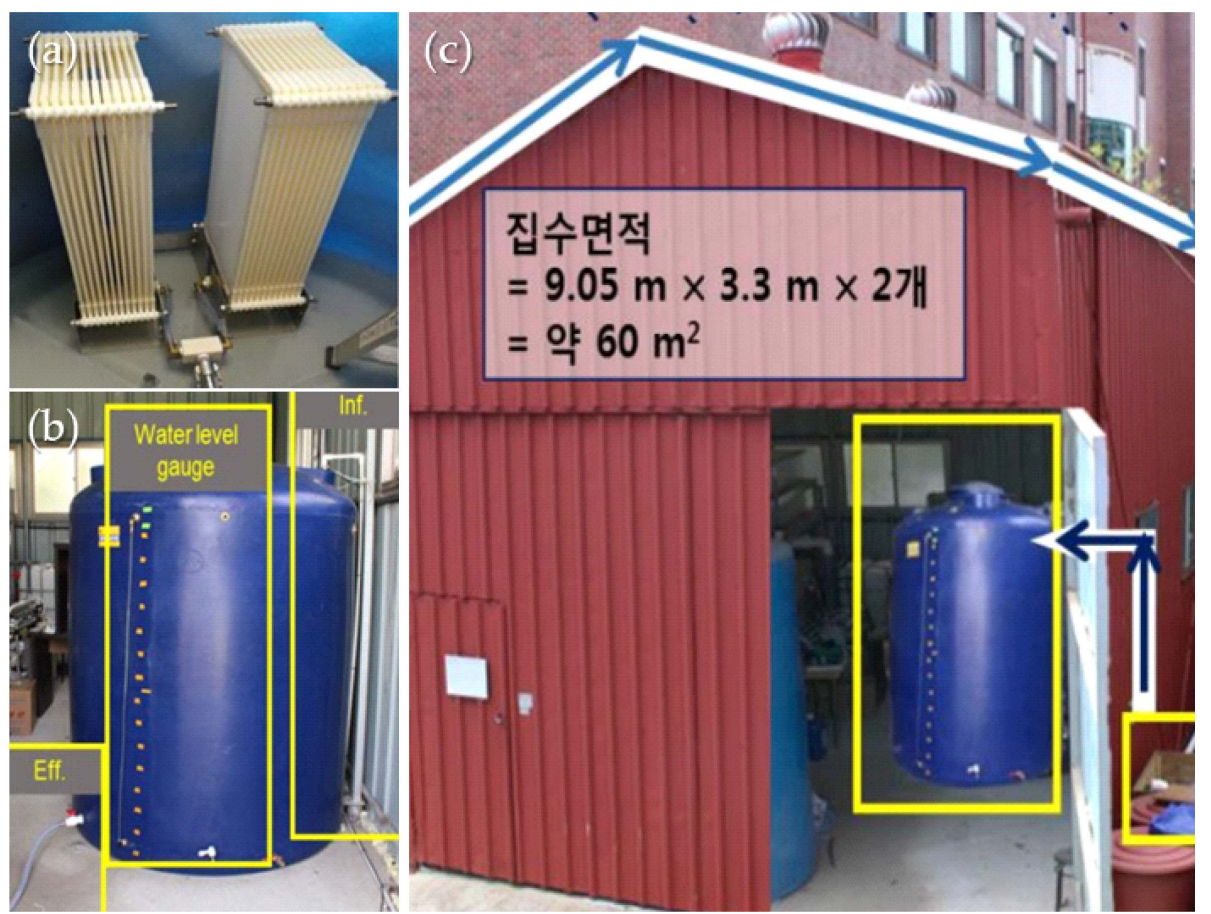

Figure 4. Photographs of (a) GDM module, (b) non-powered water purification system and (c) pilot scale.

에 배양한 후 72 시간 후 Colony의 수를 세어 먹는 물로써 가능성을 평가하였다(HPC method).

\section{4. 현장 적용 평가}

적정기술로써 무동력 정수 시스템의 현장 적용 평가 대 상지로는 기후변화에 따른 해수면 상승으로 지하수가 고갈 되어 물 부족, 위생 문제를 겪고 있는 남태평양 폴리네시아 에 있는 키리바스와 투발루를 선정하였다. 평가는 투발루와 키리바스에 각각 5 톤 용량의 수처리 설비 시설 3대씩 설치 하여 2017년 10월부터 효율 평가를 진행했으며, 물 생산량, 처 리수 수질에 대해 모니터링을 진행했다. 처리수의 수질 평 가는 휴대용 Compact dry EC, Aquagenx Kit (E. coil), Petri film (E.coil), Petri film (Aerobic bacteria) 등을 활용하였다.

\section{Results and Discussion}

\section{1. 수처리용 나노섬유 멤브레인}

Figure 5에는 PVDF 나노섬유와 친수성 고분자인 PVA (Polyvinylachol)을 표면코팅, 열 가교시켜 나노섬유 표면을 영구 친수화시킨 대표적인 표면의 주사전자 현미경 사진과 물에 대한 접촉각 결과를 나타냈다. PVDF 나노섬유의 물 에 대한 접촉각은 대략 $110 \sim 120^{\circ}$ 정도였으나 PVA 표면코 팅으로 물에 대해 완전 친수화가 이루어진 것을 확인할 수 있었다. 또한 나노섬유의 평균 직경은 $300 \mathrm{~nm}$ 였으며, 두께 $80 \sim 100 \mu \mathrm{m}$, 평균 기공 0.3 및 $0.2 \mu \mathrm{m}$ 의 나노섬유를 이용하 여 무동력 정수 시스템의 무동력 막여과 시스템용 필터여 재로 적용하였다.

Table 1. Evaluation of microbial removal performance of PVDF nanofiber filter

\begin{tabular}{|c|c|c|c|c|}
\hline \multirow{2}{*}{ Sample } & \multicolumn{3}{|c|}{ Microbial counts } & \multirow{2}{*}{ Reduction } \\
\cline { 2 - 5 } & Test Organism & Input Water & Output Water & $>99.9999$ \\
\hline \multirow{2}{*}{$\begin{array}{c}0.2 \mu \mathrm{m} \text { pore size PVDF } \\
\text { nanofiber } \\
\text { membrane }\end{array}$} & E. Coli MTCC-68 & $8 \times 10^{5} \mathrm{cfu} / \mathrm{ml}$ & $\mathrm{NVC} / 100 \mathrm{ml}$ & 99.911 \\
\cline { 2 - 5 } & $3 \mu \mathrm{m}$ Microspheres (\#24292) & $2 \times 10^{7} / \ell$ & $8 \mathrm{pfu} / 0.1 \mathrm{ml}$ & 99.99 \\
\hline \multirow{2}{*}{$\begin{array}{c}0.3 \mu \mathrm{m} \text { m pore size PVDF } \\
\text { nanofiber } \\
\text { membrane }\end{array}$} & E. Coli MTCC-68 & $6 \times 10^{5} \mathrm{cfu} / \mathrm{ml}$ & $\mathrm{NVC} / 100 \mathrm{ml}$ & $>99.9999$ \\
\cline { 2 - 5 } & MS2 phage ATCC15597B1 & $8 \times 10^{4} \mathrm{pfu} / \mathrm{ml}$ & $3 \mathrm{pfu} / 0.1 \mathrm{ml}$ & 99.962 \\
\cline { 2 - 5 } & $3 \mu \mathrm{m}$ Microspheres $(\# 24292)$ & $1.13 \times 10^{7} / \ell$ & $<160 / \ell$ & 99.99 \\
\hline
\end{tabular}




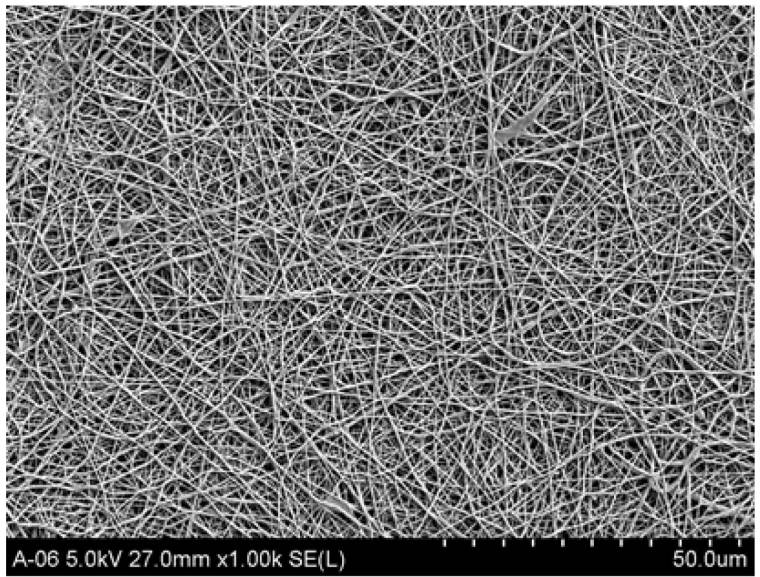

(a)

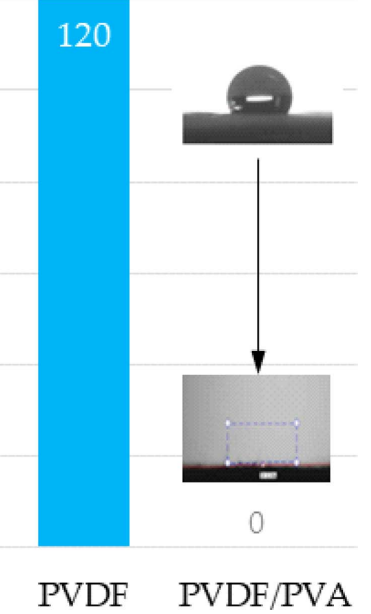

(b)

Figure 5. (a) FE-SEM images of PVDF nanofiber and (b) Result of Water Contact Angle.

Table 1에는 PVDF 나노섬유를 이용한 무동력 막여과 시 스템용 필터여재의 미생물 제거성능을 평가한 결과를 나타 냈다. 평가는 미국 $\mathrm{EPA}$ 시험규격에 따라 진행했으며, 실험 은 공식 평가 기관인 인도 Aquadianostics에 의뢰하여 평가 한 결과이다. 평가 결과 평균 기공 사이즈 0.2 및 $0.3 \mu \mathrm{m}$ PVDF 나노섬유 멤브레인 모두 E. Coli 박테리아에 대해서 는 99.9999\%(6-log), 바이러스에 대해서는 99.99\%(4-log) 이 상 제거되어 불검출되는 것을 확인하였다.

Figure 6에는 0.2 및 $0.45 \mu \mathrm{m}$ PVDF 나노섬유의 수도수 여 과시 유량 변화 결과를 나타냈다. 박테리아 6-log 제거 가 능한 필터로 초기 유량은 평균 기공 사이즈가 큰 $0.45 \mu \mathrm{m}$ 의 필터가 높은 유량을 나타냈으나 24시간 경과 후 기공 사 이즈가 작은 $0.2 \mu \mathrm{m}$ 필터와 비교해 감소하는 경향을 나타 냈다. 이러한 현상은 Hagen-Poiseuille의 식으로 설명할 수 있다. 일반적으로 다공성 막을 통한 물질의 흐름을 층류흐 름(Laminar flow)으로 가정한다면, 단위 면적당 $\mathrm{n}$ 개의 세공 을 통과하는 유체의 투과량을 체적플럭스라 하면 식 (1)과 같은 Hagen-Poiseuille 식으로 표현될 수 있다(Kim, 2010).

$$
J v=\left(\frac{n d^{4}}{128 \eta}\right) \frac{\Delta p}{l}
$$

여기에서 $J v$ : 체적플럭스,

$n$ : 단위면적당 세공수,

$d$ : 막의 지름,

$\ell$ : 막의 길이,

$\eta$ : 침투 용액의 점도,

$\Delta p$ : 막 사이의 압력차 이다.

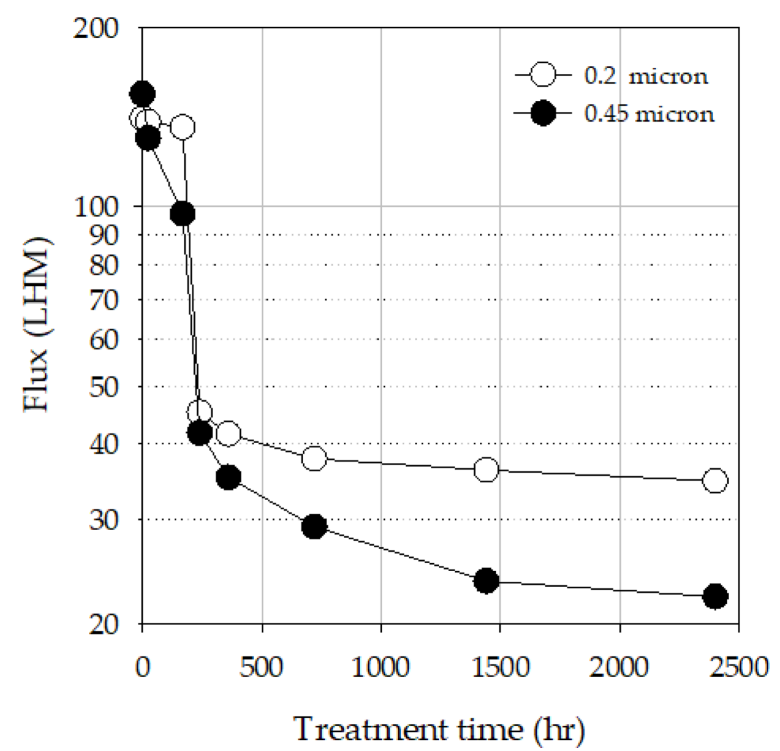

Figure 6. Changes in flux of nanofiber membrane with treatment time.

즉, 단위면적당 기공의 수는 섬유의 기공 크기에 반비례 하므로, 이러한 현상은 평균 기공의 크기가 $0.2 \mu \mathrm{m}$ 의 필터 가 $0.45 \mu \mathrm{m}$ 필터보다 단위면적당 기공의 수가 많아 보다 높 은 공극률(porosity)의 차이로 생각된다.

\section{2. 무동력 정수 시스템 Pilot test}

Figure 7에는 무동력 정수 시스템 파일럿 설비를 사용하 여 2017년 8월부터 11월까지 약 3개월간 빗물의 유속과 수 투과량 결과를 나타냈다. 성능 검증 시험 기간 중 총 4 회의 비가 내렸으며, 시간당 평균 $500 \mathrm{~L}$ 이상의 처리수가 생산되 


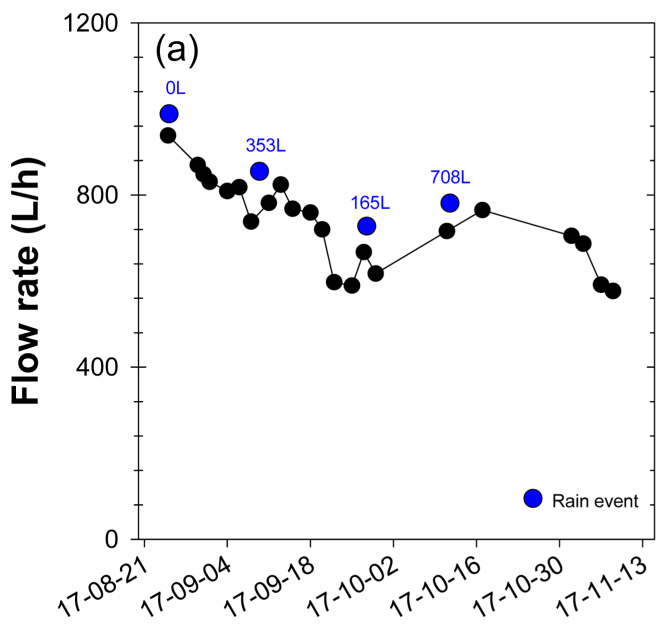

Date

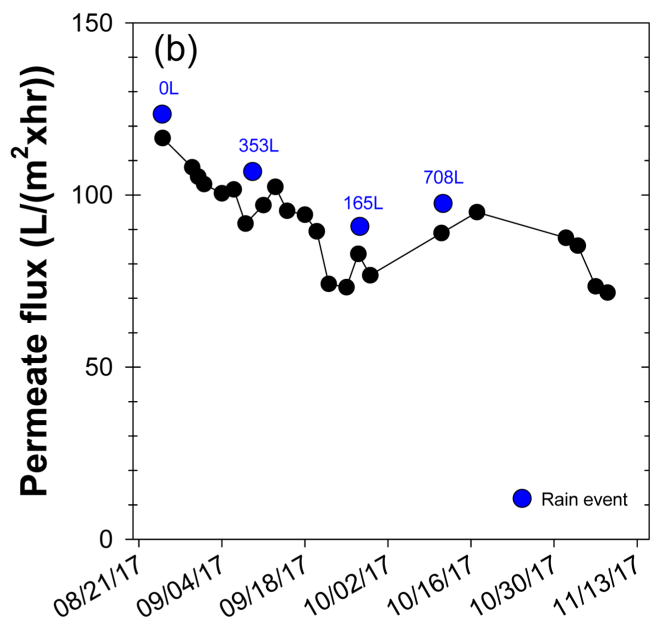

Date

Figure 7. (a) Flow rate and (b) Permeate flux results of the GDM system.

었다. 처리 유량은 평가 초기 시간당 약 $850 \mathrm{~L}$ 에서 점차 감 소하는 추세를 보였으며, 3 개월 후에는 시간당 평균 $600 \mathrm{~L}$ 로 시간이 지날수록 각종 불순물에 의한 필터의 막힘 등의 원인으로 감소하는 경향을 보였다. 평균 처리량은 $91 \pm 13 \mathrm{~L} /$ $\left(\mathrm{m}^{2} \times \mathrm{h}\right)$ 였으며, $100 \mathrm{~L}$ 의 물을 얻는 데는 평균 $8.3 \pm 1$ 분의 시 간이 소요되었다. 특히 무동력 막 여과 시스템이 적용된 무 동력 정수 시스템은 막 교체 없이 반영구적으로 수처리를 할 수 있으며, 기존 막 정수 처리 기술과는 달리 역세척이 필요하지 않아 친환경 적정기술로써 활용 가능성을 확인할 수 있었다. 특히, 막 막힘, 현지 관리인 사전교육 등의 유지 보수에 어려움이 있었으며, 현지인들의 맑은 물에 대한 인 식의 전환이 가장 먼저 해결해야할 문제로 생각된다.
Figure 8 에는 탁도와 미생물 제거 결과를 나타낸 것으로 인입수의 탁도와 3종의 미생물 수는 각각 $10.7 \mathrm{NTU}, 173 \pm 63$ $\mathrm{CFU} / \mathrm{mL}$ 에서 무동력 정수 시스템을 통과한 처리수에서 탁 도와 미생물 수는 각각 $0.1 \mathrm{NTU}$ 미만, 불검출로 $99.9 \pm 0.05 \%$ 이상 탁도 제거와 $99.99 \%$ 이상 미생물이 제거되었다. 이러 한 결과는 $\mathrm{WHO}$ 와 2011년 환경부에서 제시한 먹는 물 수 질기준 < $1 \mathrm{NTU}$ 에 적합한 탁도 수준임을 확인하였다. 일 반적으로 $0.1 \sim 10 \mu \mathrm{m}$ 의 기공 사이즈 멤브레인은 체거름을 분리 메커니즘으로 한다. 즉, 본 연구에서 박테리아 $(>2 \mu \mathrm{m})$ 와 탁도물질 $(0.2 \sim 10 \mu \mathrm{m})$ 의 높은 제거율을 볼 때 상당한 입 자성 물질의 제거뿐만 아니라 지아디아 같은 큰 병원성 미 생물 $(8 \sim 15 \mu \mathrm{m})$ 제거에 효과적일 것으로 판단된다. 더욱이,
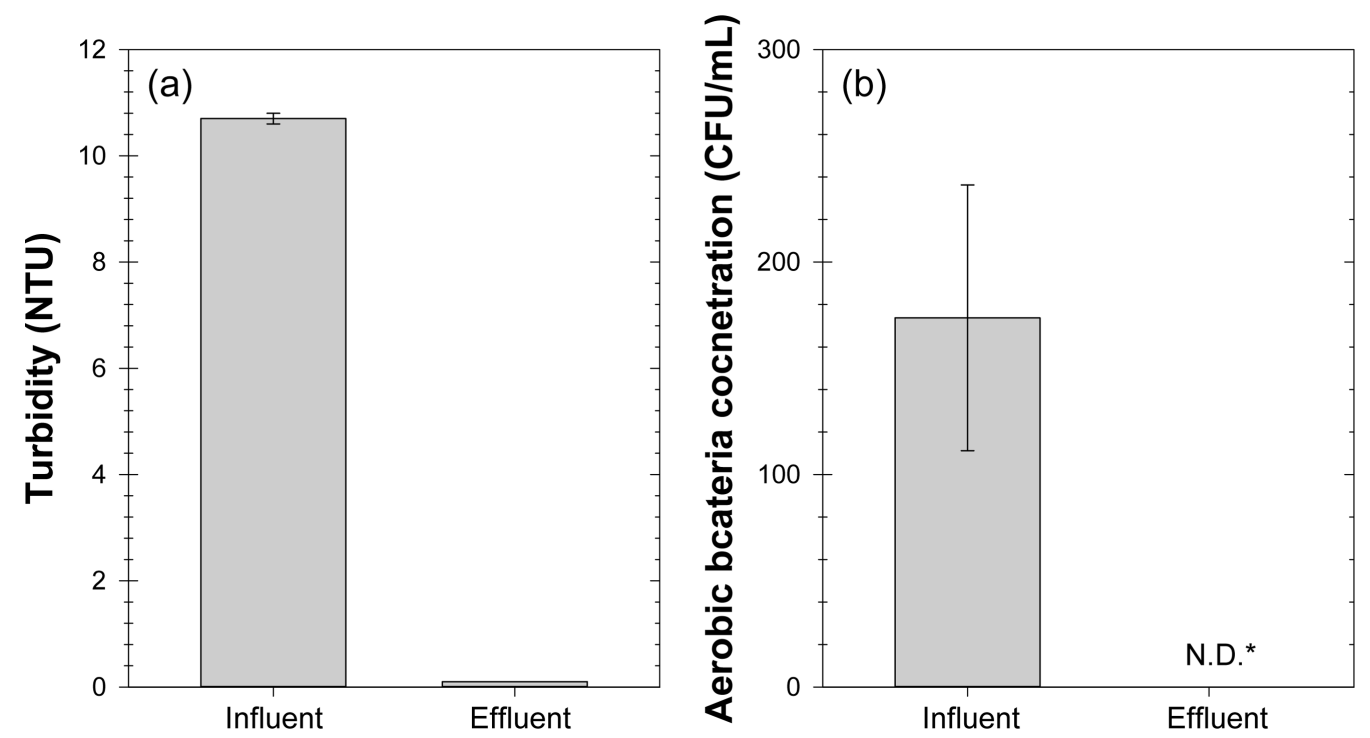

Figure 8. (a) Turbidity and (b) Bacteria removal of GDM before and after filtration. *N.D. represents not detectable. 
Table 2. Results of water quality analysis for Tuvalu sites

\begin{tabular}{|c|c|c|c|c|c|}
\hline & $\begin{array}{c}\text { Princess magaret } \\
\text { hospital }\end{array}$ & $\begin{array}{l}\text { Nauti primary } \\
\text { school }\end{array}$ & $\begin{array}{l}\text { Seventh-day adventist } \\
\text { primary school }\end{array}$ & $\begin{array}{l}\text { A house } \\
\text { at Tuvalu }\end{array}$ & $\begin{array}{c}\text { Rainwater Storage } \\
\text { Tank }\end{array}$ \\
\hline DO $(\mathrm{mg} / \mathrm{L})$ & 5 & 4 & 6.82 & 6.36 & 4.36 \\
\hline $\mathrm{pH}$ & 6.85 & 6.63 & 6.65 & 7.07 & 6.62 \\
\hline Conductivity (us/cm) & 97 & 130.4 & 42 & 68.3 & 113 \\
\hline ORP (mV) & 60 & 82.5 & 61.4 & 20.8 & 58.4 \\
\hline Turbidity & 2.2 & 0.91 & 0.82 & 0.68 & 0.56 \\
\hline Aerobic bacteria $(\mathrm{CFU} / \mathrm{ml})$ & 200 & 26 & 121 & 300 & 80 \\
\hline Total coliform $(\mathrm{CFU} / \mathrm{ml})$ & 4 & 0 & 0 & 15 & 1 \\
\hline E. Coli (CFU/ml) & 0 & 0 & 0 & 15 & 1 \\
\hline E. Coli (MPN/100ml) & 5.8 & 0 & 0 & $>100$ & $>100$ \\
\hline
\end{tabular}

탁도와 원생동물 개체수와는 밀접한 관계가 있으며, 탁도의 원인이 되는 각종 입자성 물질들을 제거하지 않으면 수많 은 병원성 미생물의 성장을 촉진할 수 있다. 따라서 무동력 막 여과 시스템을 활용한 무동력 정수 시스템은 각종 수인 성 질병을 해결 내지는 완화할 수 있는 효과가 있을 것으 로 예상된다.

\section{3. 무동력 정수 시스템 실증평가}

\section{1 키리바시 및 투발루의 물 공급 현황}

키리바시와 투발루는 태평양 적도 근처 폴리네시아에 있 는 산호섬들로 구성되어 있으며 기후변화로 수몰 위기에 직 면한 인구가 각각 10 만, 1 만 명 정도의 저개발도상 국가들
이다. 이들 국가는 평균 해발이 $1 \sim 2 \mathrm{~m}$ 의 낮은 해수면으로 기 후변화에 따른 해수면 상승에 매우 취약한 구조이며, 인구 의 $40 \%$ 이상이 수도권에 밀집되어 있어 건기시 심각한 물 부족과 수인성 질병 증가로 어려움을 겪고 있다. 투발루에 서는 주로 개별 주택에서 빗물 저장장치를 이용하여 빗물 을 모으거나 정부가 모은 빗물을 살수차를 통해 분배하여 가정에서 사용하는 실정이다.

Table 2는 투발루 현지 빗물 저장탱크의 수질 분석 결과 를 나타냈다. 대상 사이트 5곳 중 Nauti 초등학교를 제외한 3 곳의 수질은 $\mathrm{WHO}$ 의 음용수 기준 이상의 탁도 $(<1 \mathrm{NTU})$, 호기성 박테리아(기준 $<100 \mathrm{cfu} / \mathrm{ml}$ ) 및 대장균(기준 $<0 \mathrm{cfu} /$ $100 \mathrm{ml}$ ) 등이 검출되었으며, 가정집의 원수는 오염도가 심 각한 수준이었다. 빗물을 저장하는 저장탱크의 위생 상태도
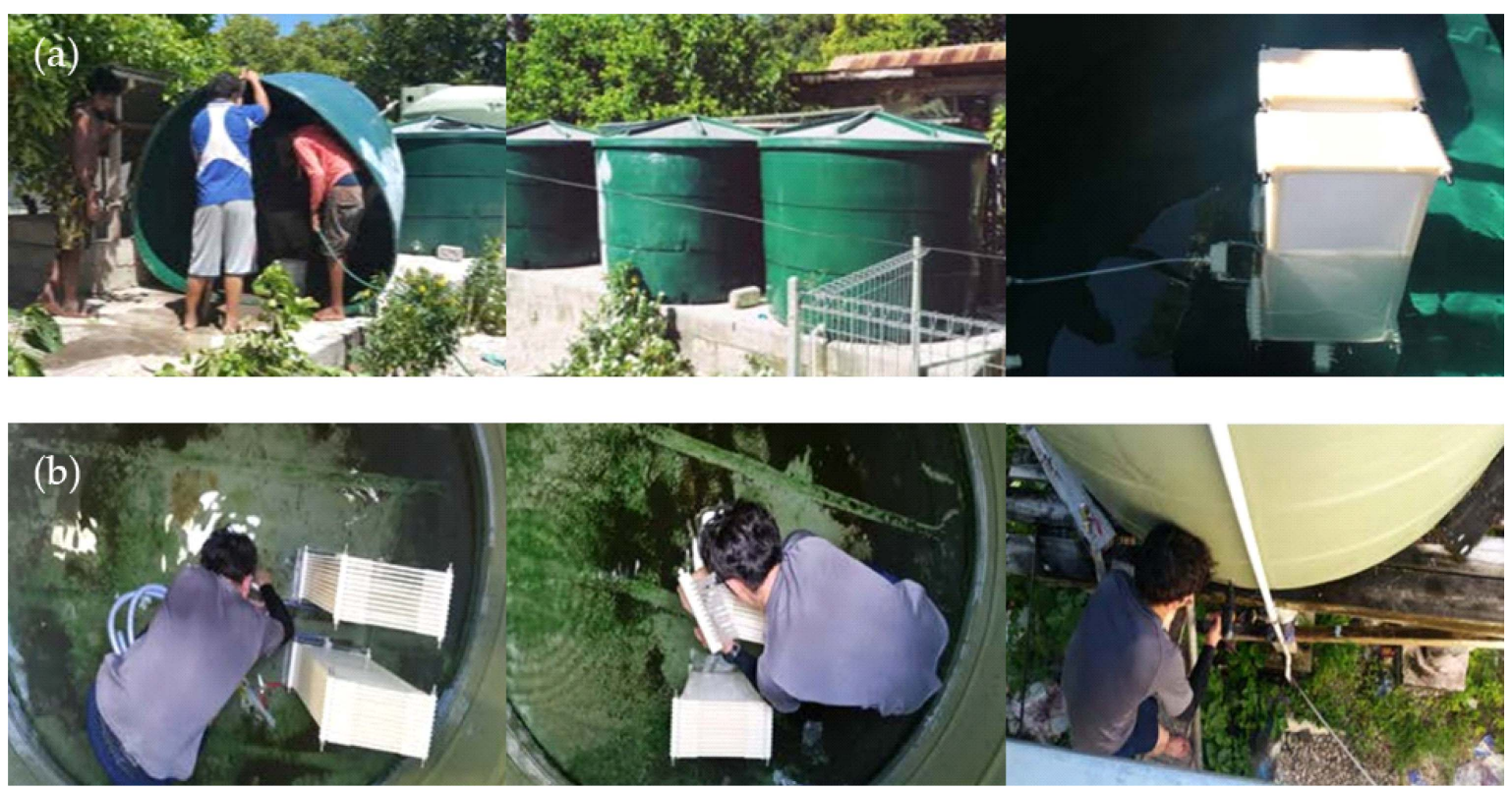

Figure 9. The photographs of non-powered water purification system installation in (a) Kiribati and (b) Tuvalu. 


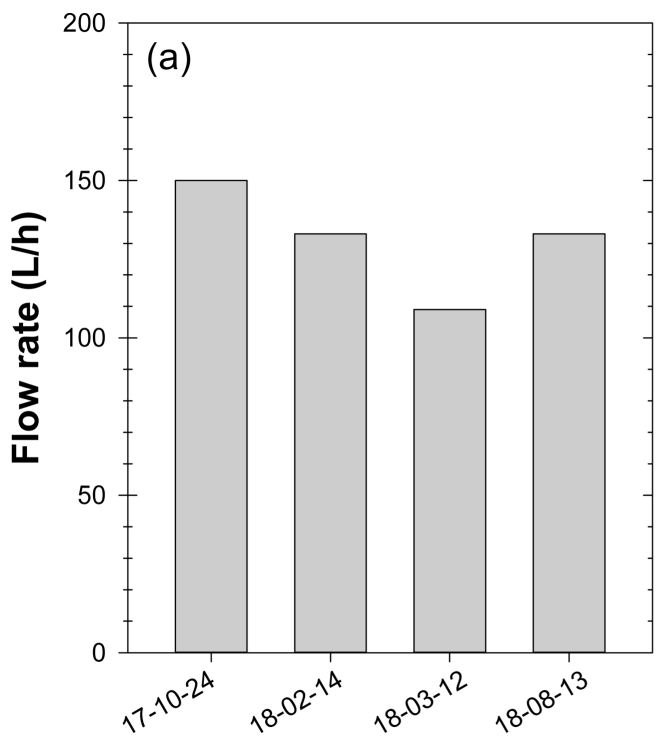

Date

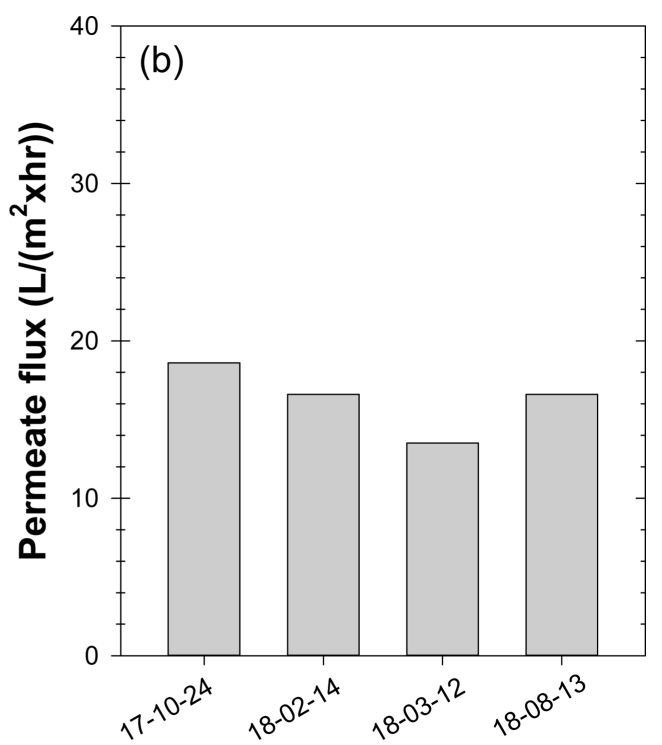

Date

Figure 10. Test results of GDM system at Taaken Bairiki Primary School's (a) Flow rate and (b) Permeate flux.

특별한 처리 없이 사용되고 있어, 수질 관리와 더불어 위생 개선이 시급한 상태였다. 비록 Nauti 초등학교의 빗물 저장 탱크의 수질이 $\mathrm{WHO}$ 음용수 기준에는 접합하였으나 호기 성 박테리아 등이 검출되어 음용수로는 적합하지 않으며, 수 인성 질병 등을 초래할 가능성이 있다.

Figure 9는 키리바시와 투발루에 설치된 내 무동력 정수 시스템 중 대표적인 사진을 나타냈다. 투발루는 적절한 크 기의 빗물 저장탱크가 없어 Fongafale 지역의 Community용 빗물 저장탱크에, 키리바시에는 Taaken Bairiki Primary School의 빗물 저장탱크에 무동력 막여과 시스템을 설치하 여 평가하였다.

Figure 10에는 키리바시 Taaken Bairiki Primary School의 무동력 막 여과 시스템의 평과 결과를 나타냈다. 실증실험 기간 처리용량은 ' 17 년 10 월 24 일 시간당 $150 \mathrm{~L}$ 에서 ' 18 년 3 월 18일 시간당 $109 \mathrm{~L}$ 로 감소하다 ' 18 년 8월 13일 시간당 $133 \mathrm{~L}$ 로 증가하였다. 이러한 현상은 키리바시 지역의 건기 로 충분한 비가 내리지 않아 발생한 현상이며 평균 처리용 량은 시간당 $131 \pm 17 \mathrm{~L}$ 를 나타냈다. 평가 기간 평균 수 투과 량은 $16.3 \pm 2 \mathrm{~L} / \mathrm{m}^{2} \mathrm{hr}$ 이었으며, 처리수 $10 \mathrm{~L}$ 를 생산하는 데 4.5

Table 3. Results of microbial removal performance of treated water using GDM

\begin{tabular}{|c|c|c|c|}
\hline & HPC & Coliform & E. coli \\
\hline $\begin{array}{c}\text { Taaken Bairiki Primary School } \\
\text { Tank }\end{array}$ & 0 & 0 & 0 \\
\hline Bairiki Community Tank & 0 & 0 & 0 \\
\hline
\end{tabular}

분이 걸렸다. Table 3 에는 무동력 막 여과 시스템을 활용한 처리수의 미생물 제거성능 결과를 나타냈다. 처리수 내 미 생물은 검출되지 않아 무동력 막 여과 시스템을 적용한 무 동력 정수 시스템이 효율적으로 미생물을 제거하는 것을 확 인하였다.

\section{4. 적정기술로써 무동력 막 여과 시스템의 해외 적용사례}

나노섬유를 적용한 중력시 막 여과장치는 현재 광주과학 기술원(GIST)의 희망 정수기 옹달샘 프로젝트의 무동력 막 여과장치로 식수원 오염 및 식수난을 겪고 있는 태평양의 도서 국가, 아프리카의 케냐, 남수단, 아이티, 몽골, 필리핀, 동남아 등 전 세계 12 개국에 안전한 식수 공급을 위해 보 급되고 있다. 무동력 막 여과 장치는 적정기술로써 전력을 사용하지 않고 음용수를 공급할 수 있는 장치로 재난지역, 상하수 처리가 부족한 낙후지역, 기후변화로 음용수를 구할 수 없는 지역에 적정기술로써 적용되고 있으며, 개도국의 식 수 및 보건 문제 해결에 도움을 지속적으로 주고 있다. 더 욱이 나노섬유 멤브레인 적용으로 상대적으로 높은 초기 물 생산성으로 긴급 재난 발생 시 효과적으로 대응할 가능성 을 나타내고 있다.

\section{Conclusions}

본 연구에서는 나노섬유 기반 무동력 막 여과 시스템을 활용한 무동력 정수 시스템의 안정적인 음용수 공급을 평 가하기 위해 파일럿과 현장 적용 평가를 하였다. 또한 먹는 
물 수질기준에 적합 여부를 평가하기 위해 탁도와 박테리 아 제거성능을 확인하였으며, 다음과 같은 결론을 얻을 수 있다.

나노섬유 멤브레인 기반 평막 필터 모듈의 박테리아 및 바이러스 제거성능을 $\mathrm{EPA}$ 기준으로 평가하여 음용수 기준 의 수질을 확보할 수 있었다. 파일럿 및 현장 적용 평가에 서는 시간당 $500 \mathrm{~L}$ 의 처리수를 얻을 수 있었으며, 각종 수 인성 전염병의 원인이 되는 E. coli, P. aeruginosa, Salmonella 와 같은 박테리아의 제거율 실험 결과 모두 불검출로 확인 되었다. 키리바시, 투발루 모두 무동력 막 여과 시스템을 적 용하였을 때 탁도, 미생물은 모두 $99.9 \%$ 이상의 제거율을 보여, $\mathrm{WHO}$ 의 먹는 물 수질기준을 만족함으로써 음용수에 적합한 수준으로 평가되었다.

본 연구를 통해 나노섬유 멤브레인 기반 무동력 막 여과 시스템은 추가적인 에너지와 막 교체 없이 장기간 높은 물 생산성과 안전한 처리수 수질을 지속적으로 생산할 가능성 을 나타내었다. 또한, 개발도상국 현장 적용 평가 및 운영 을 통해 현지 적용과 스케일 업 가능성을 확인하였다. 특히, 키리바시와 투발루에 적용한 무동력 정수 시스템은 빗물을 주요 식수원으로 사용하고 있는 남태평양 도서 국가들의 빗 물 저장탱크 내에 설치하여 안전한 식수를 지속적으로 공 급할 수 있는 적정기술로 평가되었다. 나노섬유 기반 무동 력 정수 시스템은 기후변화로 식수난을 겪고 있는 개발도 상국이나 재난, 자연재해 등 비상시에 안전한 식수 공급을 위해 전 세계로 보급되고 있으며, 전기를 사용할 수 없는 지 역에 무동력 여과 방식을 통해 적정기술로써 보급, 활용될 수 있음을 확인할 수 있었다.

\section{Acknowledgement}

본 연구는 환경부 녹색혁신기업 성장지원 사업(과제번호 202003160019)의 지원으로 이루어졌으므로 이에 감사드립 니다.

\section{References}

Kim, K.-H. (2010). Hydrology, hanteemedia, pp. 398.

Kim, Y.-M., Choi, S.-E., Park, E.-H., Lee, T., Gu, J.-E., Lee, K., and Kim, J.-H. (2015). Appropriate technology and application of non-electricity potable water purifier (Wellsping) using hollow fiber membrane, Journal of Appropriate Technology, $1(1)$, pp. $65-72$.

Cha, B.-J. and Kim, H.-S. (2012). Membrane technology and market forecast for water treatment, News \& Informaton for Chemical Engineers, 30(4), pp. 417-420.

Lee, H. D., Cho, Y. H., and Park, H. B. (2013). Current research trends in water treatment membranes based on nano materials and nano technologies, Membrane Journal, 23(2), pp. 101111.

Lee, S.-H., So, Y.-M., Jang, S.-H., Shim, H.-J., and Kim, C. (2017). A feasibility study of commercialization of PVDF nanofiber containing plasticizer, Textile Science and Engineering, 54(4), pp. 217-223.

Lee, S.-H., Jang, S.-H., So, Y.-M., Ryu, J. J., Lim, J. H., Kim, E. H., Shim, H.-J., and Kim, C. (2020). Preparation and filtration properties of a nanofiber-based composite yarn string-wound cartridge, Textile Science and Engineering, 57(1), pp. 17-24. 